\title{
Состав и распределение двустворчатых моллюсков в планктоне и бентосе пролива Невельского в летний период
}

\author{
А.В. Радовец ${ }^{1,2}$, Н.К. Колотухина ${ }^{2}$ Ю.А. Гальшева ${ }^{1}$ \\ ${ }^{1}$ Дальневосточный федеральный университет, Владивосток 690600, Россия \\ e-mail:radovets@list.ru; galysheva.yua@dvfu.ru \\ ${ }^{2}$ Наииональный научный центр морской биологии им. А.В. Жирмунского \\ ДВО РАН, Владивосток 690041, Россия \\ e-mail: kolotukhina.nata@mail.ru
}

\begin{abstract}
Исследованы видовой состав и количественное распределение двустворчатых моллюсков в меропланктоне и макробентосе прол. Невельского (северная часть Татарского пролива) в июлеавгусте 2018 г. В период наблюдений были идентифицированы представители 7 крупных таксономических групп меропланктона, включающих таксоны разного ранга. Среди них по видовому разнообразию преобладали представители Bivalvia. В меропланктоне идентифицировано 20 таксонов двустворчатых моллюсков. Из них 10 определены до вида, 4 - до рода и 6 - до семейства. Общая численность и биомасса личинок Bivalvia варьировали от 3 экз. $/ \mathrm{M}^{3}$ и 0.11 мг $/ \mathrm{M}^{3}$ до 222 экз. $/ \mathrm{M}^{3}$ и $4.11 \mathrm{мг} / \mathrm{M}^{3}$. Их максимальные значения отмечены в центральной глубоководной части пролива. Самыми многочисленными среди Bivalvia были представители семейства Astartidae. На отдельных участках численность личинок доходила до 156 экз./ $\mathrm{M}^{3}$. В макробентосе отмечено 6 видов беспозвоночных и 3 вида морских макрофитов. Доминирует Macoma balthica (биомасса от 0.1 до 148.6 г/м ${ }^{2}$, плотность

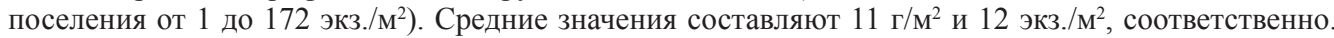
Основное скопление выявлено у восточного берега пролива, севернее м. Погиби.
\end{abstract}

Ключевые слова: пролив Невельского, Татарский пролив, двустворчатые моллюски, меропланктон, макробентос, пелагические личинки, таксономический состав, обилие, распределение.

\section{Species composition and distribution of bivalve mollusks in plankton and benthos in Nevelsky Strait in summer}

\author{
Anna V. Radovets ${ }^{1,2}$, Natalya K. Kolotukhina ${ }^{2}$, Yuliya A. Galysheva ${ }^{1}$ \\ ${ }^{1}$ Far Eastern Federal University, Vladivostok 690090, Russia \\ e-mail: radovets@list.ru; galysheva.yua@dvfu.ru \\ ${ }^{2}$ A.V. Zhirmunsky National Scientific Center of Marine Biology, \\ Far Eastern Branch, Russian Academy of Sciences, Vladivostok 690041, Russia \\ e-mail: kolotukhina.nata@mail.ru
}

Species composition and distribution of bivalve mollusks in meroplankton and macrobenthos in Nevelsky Strait (the northern part of Tatar Strait) in July-August 2018 were studied. During the observation period, representatives of seven large taxonomic groups of meroplankton, including taxa of different ranks, were found and identified. Bivalvia had the greatest species diversity in the plankton. In total, 20 taxa of bivalve mollusks were identified, among them 10 taxa were identified to species level, 4 taxa to genus level and 6 taxa to family. The total number and biomass of bivalves larvae varied from 3 ind. $/ \mathrm{m}^{3}$ and $0.11 \mathrm{mg} / \mathrm{m}^{3}$ to 222 ind. $\mathrm{m}^{3}$ and $4.11 \mathrm{mg} / \mathrm{m}^{3}$. Maximum values of bivalves were noted in the central deep-water part of the strait. Larvae of Astartidae reached the number of 156 ind. $\mathrm{m}^{3}$ were the most abundant among bivalves. 
In macrobenthos, six species of invertebrates and three species of marine macrophytes were recorded. Macoma balthica (L., 1758) dominated in the macrobenthos (biomass from 0.1 to $148.64 \mathrm{~g} / \mathrm{m}^{2}$, abundance from 1 to 172 ind. $/ \mathrm{m}^{2}$ ), the average values were $11 \mathrm{~g} / \mathrm{m}^{2}$ and $12 \mathrm{ind} . / \mathrm{m}^{2}$, respectively. The settlement with high abundance of M. balthica was found off the eastern shore of the strait, to the north of Cape Pogibi.

Key words: Nevelsky Strait, Tatar Strait, bivalve mollusks, pelagic larvae, meroplankton, macrobenthos, taxonomic composition, abundance, distribution.

Пролив Невельского - самая узкая часть Татарского пролива на севере Японского моря. Этот район относится к зоне интенсивного промышленного рыболовства [Долганова, Степаненко, 2000]. Кроме того, интерес к прол. Невельского возрос в связи с проектированием строительства мостового перехода с материка на о-в Сахалин, о котором уже довольно много говорят в открытых СМИ. С экологической точки зрения, этот район интересен специфическими условиями, связанными с интенсивной динамикой воды, опреснением под влиянием вод р. Амур и особенностями распределения донного грунта. Большая часть прол. Невельского изобилует банками и отмелями, среди которых пролегают узкие извилистые фарватеры. Центральный фарватер называется фарватером Невельского, его глубина колеблется от 10 до 20 м [Лабай, 2004]. Сочетание этих условий отличает район исследования как от типичных шельфовых мелководных бухт и заливов, так и от эстуарно-лиманных экосистем.

Имеющиеся в литературе сведения о состоянии планктона в прол. Невельского отсутствуют, а сведения по макробентосу непосредственно этого района очень малочисленны и сводятся, главным образом, к статье по бентосу прол. Невельского по материалам бентосных съемок СахНИРО 2001 и 2003 гг. [Лабай, 2004]. Кроме того, имеются немногочисленные работы по макробентосу и его отдельным таксономическим группам в прилегающих к прол. Невельского районах - Татарском проливе и Амурском лимане [Ушаков, 1953; Кобякова, 1959; Надточий, Галышева, 2012; Дуленина, 2013; Kamenev, Nekrasov, 2012]. Малочисленность сведений, несомненно, усиливает значимость выполненной работы.

Основная часть исследований, посвященных изучению видового состава и распределения личинок двустворчатых моллюсков в планктоне, проводилась ранее в северо-западной части Японского моря [Корн, Куликова, 1997; Куликова и др., 2013, 2014]. Значительно меньше внимания уделено личиночному планктону Охотского и Берингова морей и камчатских вод [Куликова, Корн, 1999]. Что касается прибрежных шельфовых вод Сахалина, имеются сведения по таксономическому составу личинок двустворчатых моллюсков только в меропланктоне зал. Анива [Куликова и др., 2017; Шпилько, Шевченко, 2018], а также данные по распределению взрослых особей двустворчатых моллюсков в северо-западной части Татарского пролива и Амурского лимана [Дуленина, 2018].

Цель настоящей работы заключалась в изучении таксономического состава, показателей обилия и особенностей распределения двустворчатых моллюсков в меропланктоне и макробентосе прол. Невельского в летний период. 


\section{Краткая характеристика района исследования}

Пролив Невельского - северная часть Татарского пролива между материковой Азией и о-вом Сахалин, соединяет Татарский пролив с Амурским лиманом и Сахалинским заливом Охотского моря. Из-за близости Амурского лимана, вода в проливе характеризуется пониженной соленостью - от 5 до 15\%. Длина пролива около 56 км, самая узкая часть 7.3 км, глубина колеблется от 0.6 м в прибрежной части пролива до 22 м в глубоководной части. В проливе много банок и отмелей, между которыми пролегают узкие фарватеры. В прибрежной части много илистых мелководий, которые в период отлива часто осушаются. Наиболее распространенный грунт - песок и ил с примесью на отдельных участках грубообломачного материала. Приливная волна формируется в северной части Татарского пролива и входит в прол. Невельского с юга. Большое влияние на приливы оказывает сток p. Амур. Величина сизигия может достигать 3 м, составляя в среднем 1.5 м. Зимой уровень прилива уменьшается относительно летнего в 1.5-2 раза [Лабай, 2004]. Существенное значение в колебании уровня воды имеют сгонно-нагонные явления. Юго-западные и западные ветры формируют значительный сгон, северо-восточные - нагон уровня воды [Лоция..., 2003].

\section{Материал и методика}

Материал собран в конце июля - начале августа 2018 г. Работы проведены на маломерном судне по четырем разрезам, на каждом из которых располагалось по 10 станций (рис. 1). Разрезы располагались по линии, соединяющей м. Погиби

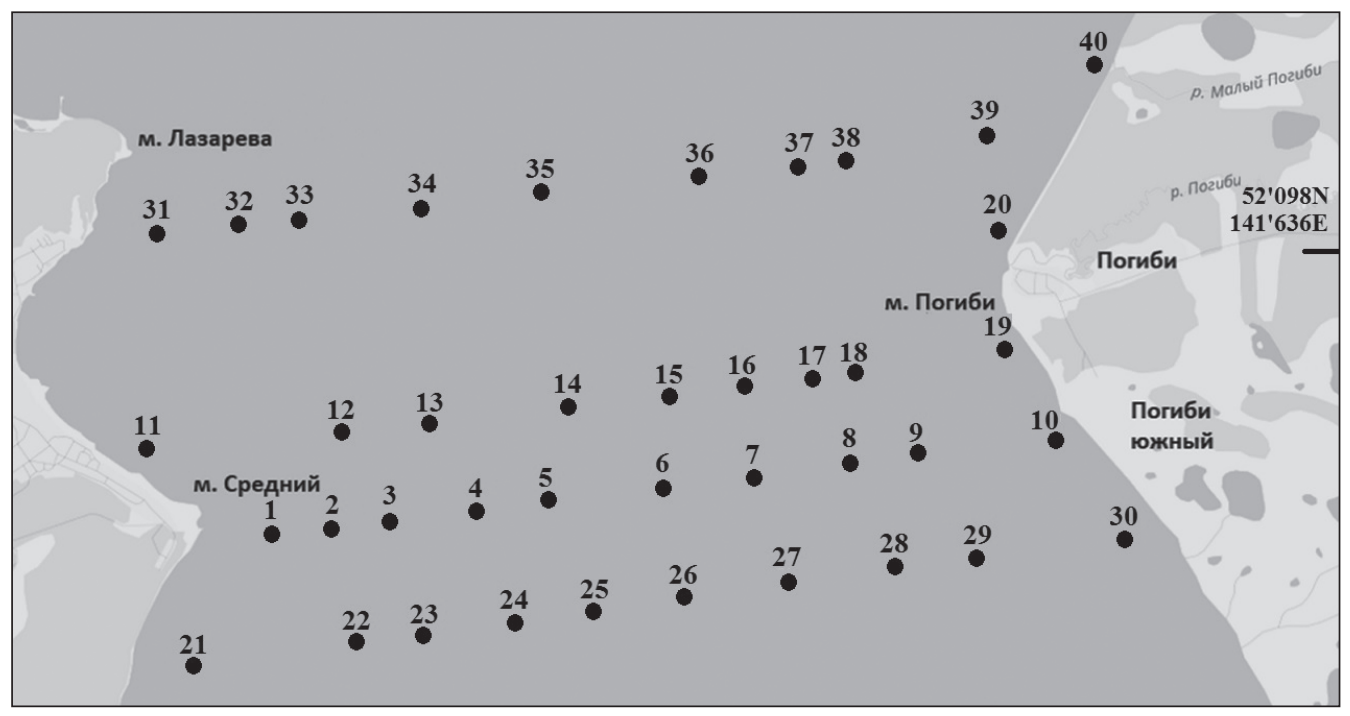

Рис.1. Карта-схема района исследований. - - станции отбора планктонных и бентосных проб.

Fig.1. A schematic map of the studied area. $\bullet$ - sampling stations. 
и м. Средний (1 разрез), а также южнее (1 разрез) и севернее (2 разреза) этой линии. Всего выполнено 40 станций, на каждой из которых отбирали планктон и бентос. Пробы планктона отбирали тотально от дна до поверхности планктонной сетью Джеди (диаметр входного отверстия 36 см, газ № 38). Глубина отбора планктонных проб варьировала от 0.6 м в мелководных западной и восточной частях пролива до 22 м в глубоководной центральной части. Всего было собрано и обработано 40 проб планктона. Параллельно с отбором проб планктона, гидрологическим батометром Gydrobios, снабженным датчиком проводились измерения температуры поверхностных и придонных слоев воды. Материал обрабатывали по стандартной методике с использованием бинокуляров МБС-10 и микроскопа «Ergaval» [Куликова и др., 2013, 2014]. Пробы планктона просматривали в камере Богорова. В зависимости от размеров планктеров, пользовались штемпель-пипеткой объемом 2 мл. Самые ранние личинки моллюсков на стадии «велигер» не были определены из-за их мелких размеров. При идентификации личинок Bivalvia на более поздней стадии (стадия «великонх») использовали определители и литературные данные [Касьянов и др., 1983; Семенихина и др., 2006; Евсеев, Колотухина, 2008]. Для определения таксономического состава и биомассы планктонных организмов использовали литературные источники и известные значения сырых весов [Полтаруха, 2008; Корниенко, Корн, 2010; и др.].

Макробентос отобран по той же сетке станций, что и планктон (всего 40 станций) дночерпателем Ван-Вина площадью захвата 0.25 м $^{2}$ в диапазоне глубин 1-23 м. Погружение и поднятие дночерпателя осуществляли на механической лебедке. Всего обработано 40 количественных проб по стандартной гидробиологической процедуре: промывке через систему трех сит с наименьшей ячеей 0.5 мм, разбору на основные таксономические группы, идентификации, подсчету и взвешиванию. Взвешивание проведено на электронных весах с точностью \pm 0.001 г. Видовая идентификация проведена с использованием определителей разных таксономических групп морских беспозвоночных. Сверка современного систематического положения организмов производилась согласно списка свободноживущих беспозвоночных дальневосточных морей, выпущенному Зоологическим институтом PAH [Sirenko, 2013], а также всемирной электронной базе данных WoRMS. Материал предоставлен ООО НПФ «Экоцентр МТЭА».

\section{Результаты и обсуждение}

Всего в меропланктоне прол. Невельского в конце июля - начале августа 2018 г. были идентифицированы представители 7 крупных таксономических групп, включающих таксоны разного ранга (см. таблицу). По видовому разнообразию в период наблюдений преобладали представители Bivalvia. Определение значительной части видов других таксономических групп было затруднено из-за их недостаточной изученности. 
Таксономический состав, численность и биомасса меропланктона пролива Невельского в летний период 2018 г.

Taxonomic composition, abundance and biomass of meroplankton in Nevelsky Strait in summer 2018

\begin{tabular}{|c|c|c|c|c|c|c|}
\hline \multirow{2}{*}{$\begin{array}{c}\text { Таксономический состав } \\
\text { планктона }\end{array}$} & \multicolumn{3}{|c|}{ Численность, экз./м³ } & \multicolumn{3}{|c|}{ Биомасса, мг $/ \mathrm{M}^{3}$} \\
\hline & $\begin{array}{c}\text { мини- } \\
\text { мальная }\end{array}$ & средняя & $\begin{array}{c}\text { макси- } \\
\text { мальная }\end{array}$ & $\begin{array}{c}\text { мини- } \\
\text { мальная }\end{array}$ & средняя & $\begin{array}{c}\text { макси- } \\
\text { мальная }\end{array}$ \\
\hline \multicolumn{7}{|c|}{$\begin{array}{c}\text { Тип Mollusca } \\
\text { Класс Bivalvia } \\
\text { Отряд Carditida } \\
\text { Семейство Astartidae }\end{array}$} \\
\hline Astartidae gen. sp. & 1 & 15.25 & 156 & 0.007 & 0.106 & 1.09 \\
\hline \multicolumn{7}{|c|}{ Отряд Venerida } \\
\hline Ruditapes philippinarum & 1 & 0.3 & 8 & 0.007 & 0.002 & 0.056 \\
\hline Callista brevisiphonata & 1.6 & 0.14 & 4 & 0.007 & 0.0009 & 0.03 \\
\hline Mercenaria stimpsoni & 1 & 0.06 & 1.6 & 0.007 & 0.0004 & 0.011 \\
\hline Veneridae gen. sp. & 1 & 0.08 & 1.6 & 0.007 & 0.0005 & 0.011 \\
\hline \multicolumn{7}{|c|}{ Семейство Mactridae } \\
\hline Mactra chinensis & 1.74 & 0.3 & 5 & 0.012 & 0.002 & 0.035 \\
\hline Spisula sp. & 2 & 0.1 & 2 & 0.014 & 0.0007 & 0.014 \\
\hline \multicolumn{7}{|c|}{ Семейство Cyrenidae } \\
\hline Corbicula japonica & 2 & 0.3 & 10 & 0.014 & 0.002 & 0.07 \\
\hline \multicolumn{7}{|c|}{ Отряд Mytilida } \\
\hline \multicolumn{7}{|c|}{ Семейство Mytilidae } \\
\hline Mytilus trossulus & 1 & 0.28 & 5.4 & 0.007 & 0.002 & 0.04 \\
\hline Crenomytilus grayanus & 1 & 0.07 & 2 & 0.007 & 0.0005 & 0.014 \\
\hline Mytilidae gen. sp. & 1 & 0.25 & 2 & 0.007 & 0.001 & 0.014 \\
\hline \multicolumn{7}{|c|}{$\begin{array}{c}\text { Отряд Adapedonta } \\
\text { Семейство Hiatellidae }\end{array}$} \\
\hline Hiatella arctica & 1 & 0.025 & 2 & 0.007 & 0.00017 & 0.014 \\
\hline \multicolumn{7}{|c|}{ Семейство Pharidae } \\
\hline Siliqua alta & 1 & 0.1 & 2 & 0.007 & 0.0007 & 0.014 \\
\hline \multicolumn{7}{|c|}{$\begin{array}{c}\text { Отряд Ostreida } \\
\text { Семейство Ostreidae }\end{array}$} \\
\hline Crassostrea gigas & 1 & 0.075 & 2 & 0.007 & 0.0005 & 0.014 \\
\hline \multicolumn{7}{|c|}{$\begin{array}{c}\text { Отряд Cardiida } \\
\text { Семейство Cardiidae }\end{array}$} \\
\hline Cardiidae gen. sp. & 1 & 0.11 & 4.55 & 0.007 & 0.0007 & 0.14 \\
\hline \multicolumn{7}{|c|}{ Семейство Tellinidae } \\
\hline Tellinidae gen. sp. & 1 & 0.075 & 2 & 0.007 & 0.0005 & 0.014 \\
\hline \multicolumn{7}{|c|}{$\begin{array}{l}\text { Отряд Galeommatida } \\
\text { Семемейство Lasaeidae }\end{array}$} \\
\hline Mysella sp. & 1 & 0.025 & 1 & 0.007 & 0.00017 & 0.007 \\
\hline
\end{tabular}


Окончание таблицы

\begin{tabular}{|c|c|c|c|c|c|c|}
\hline \multirow{2}{*}{$\begin{array}{c}\text { Таксономический состав } \\
\text { планктона }\end{array}$} & \multicolumn{3}{|c|}{ Численность, экз./M ${ }^{3}$} & \multicolumn{3}{|c|}{ Биомасса, мг/м ${ }^{3}$} \\
\hline & $\begin{array}{c}\text { мини- } \\
\text { мальная }\end{array}$ & средняя & $\begin{array}{c}\text { макси- } \\
\text { мальная }\end{array}$ & $\begin{array}{c}\text { мини- } \\
\text { мальная }\end{array}$ & средняя & $\begin{array}{c}\text { макси- } \\
\text { мальная }\end{array}$ \\
\hline \multicolumn{7}{|c|}{ Отряд Myida } \\
\hline \multicolumn{7}{|c|}{ Семейство Myidae } \\
\hline Mya sp. & 2 & 0.31 & 8 & 0.014 & 0.002 & 0.056 \\
\hline \multicolumn{7}{|c|}{ Семейство Pholadidae } \\
\hline Pholadidae gen. sp. & 1 & 0.06 & 1.75 & 0.007 & 0.0004 & 0.012 \\
\hline \multicolumn{7}{|c|}{ Надотряд Anomalodesmata } \\
\hline Lyonsia sp. & 2 & 0.11 & 2.7 & 0.014 & 0.0008 & 0.018 \\
\hline \multicolumn{7}{|c|}{$\begin{array}{c}\text { Класс Gastropoda } \\
\text { Отряд Littorinimorpha } \\
\text { Семейство Naticidae }\end{array}$} \\
\hline Cryptonatica janthostoma & 1 & 41.28 & 303 & 0.009 & 0.371 & 3.03 \\
\hline \multicolumn{7}{|c|}{$\begin{array}{c}\text { Тип Arthropoda } \\
\text { Подкласс Thecostraca } \\
\text { Инфракласс Cirripedia } \\
\text { Надотряд Thoracica } \\
\text { Семейство Chthamalidae }\end{array}$} \\
\hline Chthamalus dalli науплии & 1 & 0.23 & 8 & 0.023 & 0.005 & 0.184 \\
\hline Chthamalus dalli циприс & 1.38 & 11.38 & 227 & 0.027 & 0.22 & 4.55 \\
\hline \multicolumn{7}{|c|}{$\begin{array}{c}\text { Класс Malacostraca } \\
\text { Подкласс Eumalacostraca } \\
\text { Отряд Decapoda } \\
\text { Инфраотряд Brachyura } \\
\text { Семейство Varunidae }\end{array}$} \\
\hline Hemigrapsus sp. зоэа & 1.81 & 47.49 & 1900 & 0.18 & 4.72 & 121.48 \\
\hline Hemigrapsus sp. мегалопа & 1 & 0.07 & 1.85 & 1.11 & 0.79 & 11.11 \\
\hline \multicolumn{7}{|c|}{ Семейство Pinnotheridae } \\
\hline Pinnixa sp. зоэа & 2 & 64.38 & 2057 & 0.2 & 6.43 & 131.52 \\
\hline \multicolumn{7}{|c|}{ Семейство Macrophthalmidae } \\
\hline $\begin{array}{l}\text { Tritodynamia rathbunae } \\
\text { зоэа }\end{array}$ & 1.91 & 0.047 & 1.91 & 0.19 & 0.004 & 0.19 \\
\hline \multicolumn{7}{|c|}{ Инфраотряд Anomura } \\
\hline Anomura fam. spp. зоэа & 1 & 0.025 & 1 & 0.53 & 0.013 & 0.53 \\
\hline \multicolumn{7}{|c|}{$\begin{array}{c}\text { Тип Annelida } \\
\text { Класс Polychaeta } \\
\text { Отряд Phyllodocida } \\
\text { Семейство Phyllodocidae }\end{array}$} \\
\hline Phyllodocidae gen. spp. & 2.3 & 6.45 & 200 & 0.04 & 0.112 & 2 \\
\hline \multicolumn{7}{|c|}{ Отряд Spionida } \\
\hline Spionidae gen. spp. & 1 & 94.67 & 2142 & 0.002 & 0.189 & 21.42 \\
\hline
\end{tabular}


За время наблюдений было идентифицировано 20 таксонов личинок двустворчатых моллюсков, среди которых 10 определены до вида, 4 - до рода и 6 - до семейства. Общая численность и биомасса личинок варьировали от 3 экз./ $\mathrm{M}^{3}$ и $0.11 \mathrm{мг} / \mathrm{M}^{3}$ (станция 19) до 222 экз./ $\mathrm{M}^{3}$ и $4.11 \mathrm{мг} / \mathrm{M}^{3}$ (станция 22) (см. таблицу). Глубина отбора проб на данных станциях составляла 0.9 и 2.2 м, соответственно, температура поверхностных и придонных слоев воды на обеих станциях была около $17.0^{\circ} \mathrm{C}$. Самыми многочисленными среди Bivalvia были представители семейства Astartidae, максимальная численность которых доходила до 156 экз./м³ (станция 5), составляя в среднем 15 экз./м³ на станцию. Глубина отбора проб на данной станции составляла 15 м, температура поверхностных и придонных слоев воды была $17.9^{\circ} \mathrm{C}$ и $16.7^{\circ} \mathrm{C}$, соответственно. По таксономическому составу преобладали представители сем. Veneridae, включающего Ruditapes philippinarum (Adams et Reeve, 1850), Callista brevisiphonata (Carpenter, 1864), Mercenaria stimpsoni (Gould, 1861) и других, не идентифицированных до вида представителей семейства. Численность $R$. philippinarum составляла 1-8 экз. $/ \mathrm{M}^{3}$, C. brevisiphonata $-1.6-4$ экз. $/ \mathrm{M}^{3}$, M. stimpsoni и остальных представителей данного семейства - 1-1.6 экз./м³. При этом больше всего личинок отмечено на станциях 16 и 35, расположенных в центральной части пролива на глубине 15 и 23 м, при температуре поверхностных и придонных воды слоев $17.9^{\circ} \mathrm{C}$ и $16.5-17.4^{\circ} \mathrm{C}$. На втором месте по видовому разнообразию было семейство Mytilidae: Mytilus trossulus (Gould, 1850), Crenomytilus grayanus (Dunker, 1853) и не идентифицированные до вида представители данного семейства. Численность M. trossulus составляла: $1-5.4$ экз./ $\mathrm{M}^{3}$, C. grayanus и остальных представителей сем. Mytillidae - 1-2 экз./M‥ Большее число личинок митилид было также отмечено на центральных станциях пролива - 17 и 38, расположенных на глубине 10 и 15 м, при температуре поверхностных и придонных слоев воды $17-17.8^{\circ} \mathrm{C}$ и $16.8^{\circ} \mathrm{C}$, соответственно. Семейство Mactridae включало два представителя: Mactra chinensis (Philippi, 1846) и Spisula sachalinensis (Schrenck, 1861). Численность M. chinensis составляла 2-5 экз./ $\mathrm{M}^{3}$, S. sachalinensis - 2 экз./ $\mathrm{M}^{3}$ на центральных станциях пролива $14,35-36$, расположенных на глубине 10 и 15-22 м, при температуре поверхностных и придонных слоев воды $17.8^{\circ} \mathrm{C}$ и $16.1-17.4^{\circ} \mathrm{C}$, соответственно.

Семейства Hiatellidae, Cyrenidae, Ostreidae и Pharidae включали по одному представителю: Hiatella arctica (L., 1767), Corbicula japonica Prime, 1864, Crassostrea gigas (Thunberg, 1793) и Siliqua alta (Broderip et Sowerby, 1829). Численность личинок H. arctica, C. gigas и S. alta составляла: 1-2 экз./м², количество личинок C. japonica составляло 2-10 экз./м³. Личинки этих видов встречались на центральных станциях пролива 17, 35 и 36, при глубинах и температуре, указанных выше. Остальные представители Bivalvia - сем. Cardiidae, сем. Lasaeidae (Mysella sp.), сем Tellinidae, сем. Pholadidae, сем. Lyonsiidae (Lyonsia sp.), сем. Myidae (Mya sp.) встречались в планктоне в количестве от 1 до 8 экз./ $\mathrm{M}^{3}$ (см. таблицу) преимущественно на центральных станциях 16, 17, 36 и 38. 
По-видимому, близость Амурского лимана влияет на численность и видовой состав Bivalvia из-за пониженной солености по сравнению с другими акваториями Татарского пролива. Фауна прол. Невельского представлена как морскими представителями (сем. Astartidae, Veneridae, Mytillidae, Mactridae, Hiatellidae, Ostreidae, Pharidae, Cardiidae, Lasaeidae, Tellinidae, Pholadidae, Lyonsiidae), так и солоноватоводным видом C. japonica. Среди идентифицированных до вида представителей Bivalvia преобладали бореальные и субтропические виды - $50 \%$ и $40 \%$ от общего числа видов, соответственно. На долю арктических представителей приходилось всего $10 \%$ от общего числа идентифицированных видов двустворчатых моллюсков.

Преобладание в планктоне личинок сем. Astartidae - относительно глубоководных моллюсков, чьи личинки слабо изучены и упоминание о которых имеется только в работе Риса [Rees, 1950], по-видимому, связано с наличием массовых скоплений взрослых особей в близлежащем к району исследований Татарском проливе [Дуленина, 2013]. Преимущественное концентрирование личинок Bivalvia у западного берега пролива в районе м. Средний, а также в центральной глубоководной его части, очевидно обусловлено работой течений, которые захватывают планктеров у побережья в районе м. Погиби и других мелководных частях пролива, выносят на глубину в центральную часть и концентрируют их у противоположного берега. Видовое разнообразие личинок Bivalvia прол. Невельского и некоторых районов Японского моря достаточно сходны [Корн, Куликова, 1997; Куликова, Корн, 1999; Куликова и др., 2013; и др.].

Общая численность отряда Decapoda - второго по видовому разнообразию представителя меропланктона, в период наблюдений варьировала от 8 до 3961 экз./ $\mathrm{M}^{3}$, биомасса - от 12.21 до $254.83 \mathrm{мг} / \mathrm{M}^{3}$, достигая максимальных значений на станции 8. В период наблюдений отряд Decapoda включал 4 представителей: Hemigrapsus sp. на стадии зоэа в количестве от 2 до 1900 экз./ ${ }^{3}$, в среднем 47 экз. $/ \mathrm{M}^{3}$ на станцию, биомассой от 0.18 до $121.48 \mathrm{мг} / \mathrm{M}^{3}$, в среднем $4.72 \mathrm{Mг} / \mathrm{M}^{3}$ и на стадии мегалопы в количестве 1-2 экз./ $\mathrm{M}^{3}$ биомассой $1.11-11.1 \mathrm{мг} / \mathrm{M}^{3}$ (см. таблицу), Pinnixa sp. на стадии зоэа - от 2 до 2057 экз. $/ \mathrm{m}^{3}$, в среднем 64 экз./ $\mathrm{m}^{3}$, биомассой от 0.2 до $131.52 \mathrm{мг} / \mathrm{M}^{3}$, в среднем $6.43 \mathrm{мг} / \mathrm{M}^{3}$ и зоэа Tritodynamia rathbunae (Shen, 1932) и не идентифицированных до вида представителей инфраотряда Anomura встретившихся единично на одной из станции пролива.

Среди других представителей меропланктона в большом количестве встречались личинки полихет сем. Spionidae - от 1 до 2142 экз./ $\mathrm{M}^{3}$, в среднем 954 экз./ ${ }^{3}$, биомассой от 0.002 до $21.42 \mathrm{мг} / \mathrm{M}^{3}$, в среднем $0.189 \mathrm{мг} / \mathrm{M}^{3}$. Остальные группы организмов меропланктона встречались редко и в небольшом количестве. По имеющимся данным [Куликова и др., 2017], в ближайшем к проливу исследованном районе - зал. Анива, в меропланктоне летом 2009-2011 гг. встречались такие же виды (M. coruscus, M. trossulus, C. grayanus и др.) и личинки других двустворчатых моллюсков наряду с представителями сем. Naticidae (Gastropoda), сем. Phyllodocidae 
и Spionidae (Polychaeta), Hemigrapsus sp. и Pinnixa sp. (Decapoda) и Chthamalus dalli Pilsbry, 1916 (Cirripedia). При этом, представителей сем. Astartidae отмечено в планктоне не было.

Структура макробентоса в прол. Невельского по результатам анализа дночерпательных пробах крайне проста. Всего обнаружено 6 видов беспозвоночных: гидроидный полип Abietinaria sp. (Hydrozoa), полихета Arenicolidae gen. sp. (Polychaeta) и двустворчатые моллюски из семейства Tellinidae (Macoma balthica (L., 1758), Macoma sp. 1, Macoma sp. 2, Tellinidae gen.sp. 3). Из растений-макрофитов обнаружены остатки морской травы Zostera marina (L., 1753), а также небольшие фрагменты талломов бурых водорослей родов Sargassum и Chordaria. Наибольшей частотой встречаемости характеризуется двустворчатый моллюск M. balthica, который присутствовал в $67.5 \%$ всех проб и 100\% проб, где был макробентос как таковой.

Значения биомассы макробентоса определялись M. balthica и варьировали

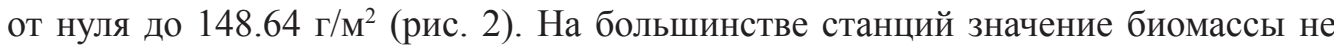
превышало 20 г/ $\mathrm{M}^{2}$, на трех станциях (4, 28 и 36) биомасса лежала в диапазоне 20-40 г/м², и лишь одна станция (39) выделялась существенно более высоким значением, составляющим максимум в полученном ряду. На двенадцати станциях из сорока (32.5\%) макробентос в составе дночерпательных проб обнаружен не был. Численность изменялась в пределах от нуля до 172 экз./м². Поскольку макробентос представлен в основном одним видом, распределение значений численности по станциям сопряжено с распределением значений биомассы.

Горизонтальное распределение биомассы по дну изучаемого пространства пятнистое (неоднородное). Максимальное значение выявлено у восточного берега

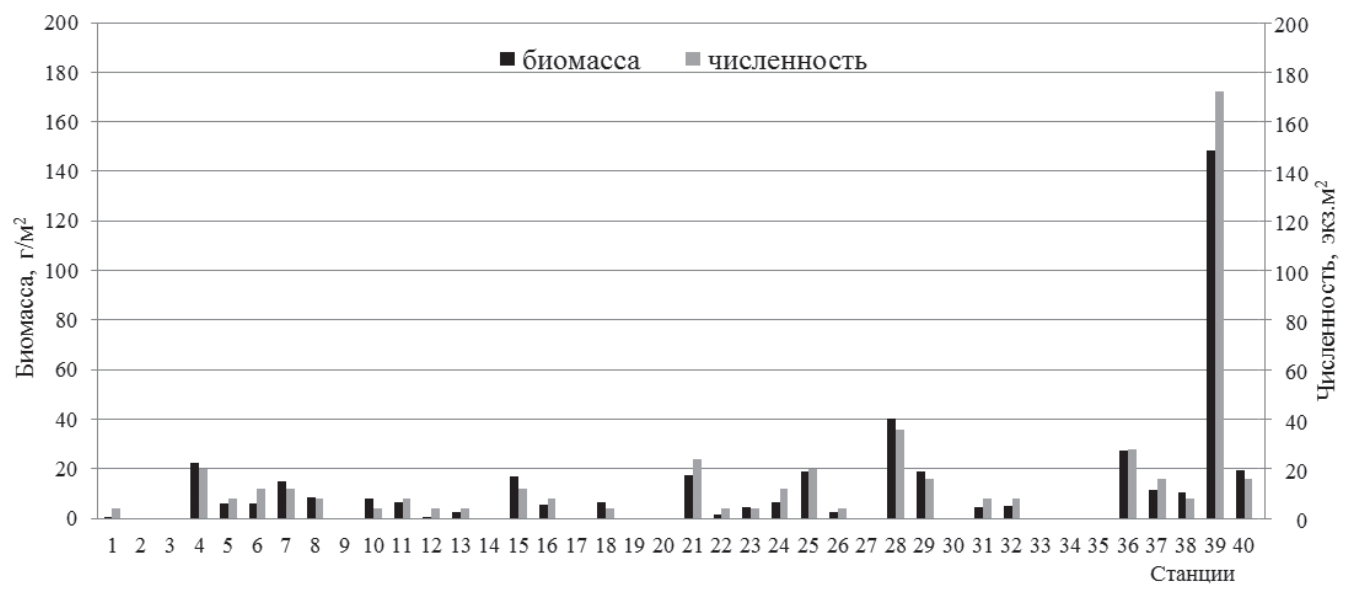

Рис. 2. Распределение значений биомассы и численности Macoma balthica по станциям отбора проб.

Fig. 2. Distribution of the Macoma balthica biomass and abundance values at sampling stations. 
пролива (севернее м. Погиби) хотя для большинства станций в этом районе харак-

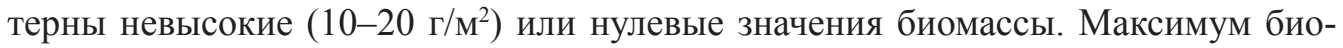
массы формировался $M$. balthica (рис. 3) и соответствовал пространственному расположению пика биомассы этого вида, зафиксированному по данным предшествующих авторов [Kamenev, Nekrasov, 2012]. В центральной части общая биомасса распределялась в диапазоне от 10 до 40 г/ ${ }^{2}$, у западного берега значения наиболее низкие - преимущественно до 10 г/ $\mathrm{M}^{2}$. Пространственное распределение численности практически повторяет распределение биомассы.

В целом, все изученное пространство является зоной сообщества M. balthica. Однако характеристика сообщества на основе однократной съемки недостоверна и полное описание видового состава требует повторения отбора проб. Насколько устойчив обнаруженный олиговидовой комплекс, позволят оценить сезонные межгодовые исследования. Не исключается влияние фактора опреснения и штормовой деятельности, которые могут временно существенно обеднять биоценозы. Тем не менее, в результатах ранее выполненных в проливе исследований [Лабай, 2004] макома балтийская указана в качестве доминанта.

В ретроспективных данных, полученных ТИНРО в 1985 г. [Надточий, Галышева, 2012], северная часть Татарского пролива, в которую входит прол. Невельского, характеризуется схожими значениями биомассы около 100 г/м ${ }^{2}$. Район отнесен к зоне доминирования Bivalvia (без уточнения видов-доминантов).

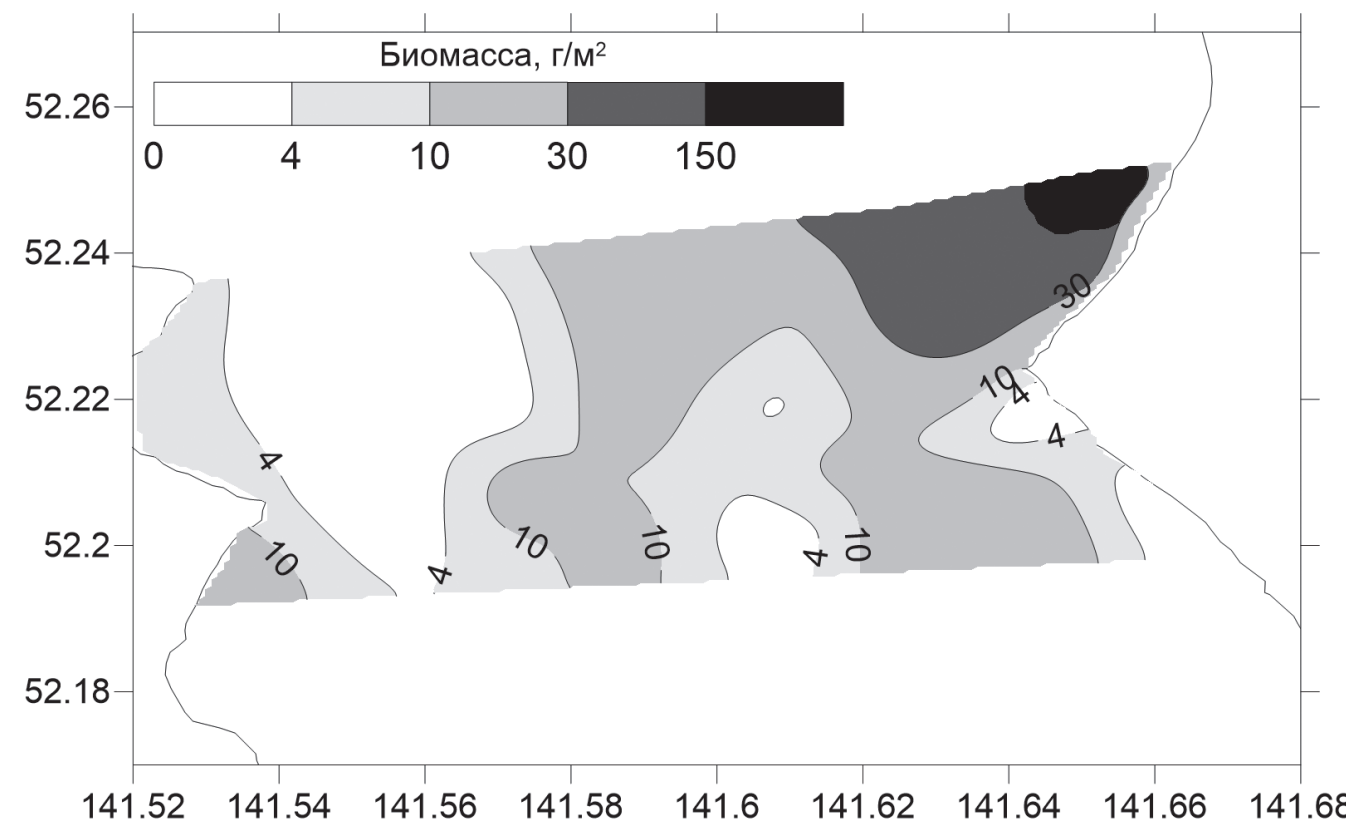

Рис. 3. Карта-схема пространственного распределения биомассы Macoma balthica.

Fig. 3. A schematic map of the spatial distribution of the Macoma balthica biomass. 
В работах же, посвященных фауне двустворчатых моллюсков, прилегающих к прол. Невельского районов [Дуленина, 2013; Kamenev, Nekrasov, 2012], M. balthica конкретно указывается в ряду доминирующих видов.

Сложность гидрологических условий и меняющиеся условия солености являются определяющими факторами, влияющими на обеднение биоты в прол. Невельского в целом. Наибольшего богатства бентоса в таких условиях следует ожидать в наиболее мелководной (литораль - верхняя сублитораль) части, где залегают наиболее стабильные грубообломочные субстраты. Однако эта зона не была охвачена отбором проб.

Опираясь на имеющиеся литературные данные о разнообразии экологических условий на разной глубине прол. Невельского [Лабай, 2004], можно предполагать достаточно полный охват условий гидродинамики и донных субстратов в данном районе, имеющих важнейшее значение для распределения бентоса и формирования его состава. Присутствующий в пробах субстрат по гранулометрической оценке доминирующей фракции классифицируется на следующие категории (рис. 4): галька мелкая (ГМ), гравий (Гр) песок (П), ил (И), биогенные остатки (БО) - обрывки морской травы. Большая часть проб с присутствием грубообломочного материала (галька мелкая и гравий) была отобрана на станциях с глубиной до 10 м. Присутствие (доминирование) грубообломочного материала свидетельствует об интенсивных гидродинамических условиях, при которых сформировался субстрат, а, следовательно, и обитает бентос. Песок и ил аккумулируются в более спокойных условиях движения воды; по данным анализа проб - в большей степени на мелководье. Пробы, в которых присутствовали биогенные остатки (обрывки морской травы), были отобраны на наименьших глубинах.

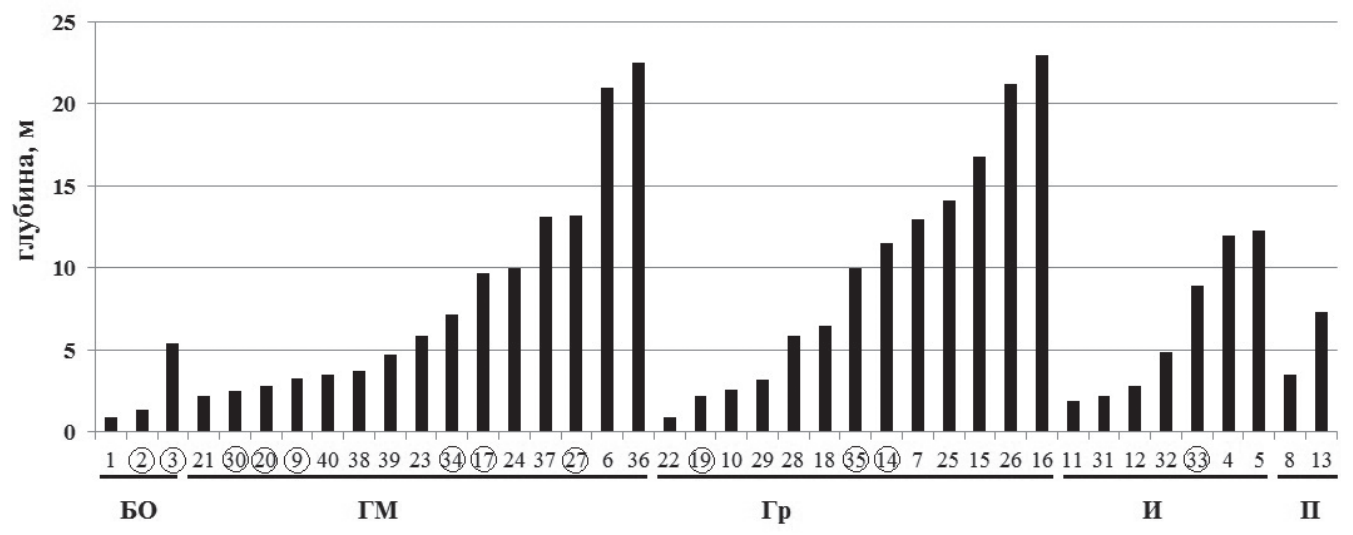

Рис. 4. Распределение станций отбора проб по глубине и типу грунта (кружком обведены станции, на которых макробентос не обнаружен; БО - биогенные остатки, ГМ - галька мелкая, Гр - гравий, И - ил, П - песок).

Fig. 4. Distribution of sampling stations by depth and type of bottom sediments (circles are around the stations where no macrobenthos was detected; БО - biogenic residues, $\mathbf{\Gamma M}$ - pebbles, $\Gamma \mathbf{p}$ - gravel, $\mathbf{U}$ - silt, $\Pi$ - sand). 
Наложение данных об отсутствии макробентоса на гистограмму распределения станций по глубине и доминирующей фракции субстрата в пробе показывает, что наибольшее число таких случаев характерно для проб с присутствием грубообломочного материала (гальки мелкой) в горизонте до 15 м, где, вероятно формируются наиболее неблагоприятные в отношении бентоса условия среды (рис. 4).

Однофакторный анализ зависимости биомассы и численности макробентоса от глубины и доминирующей фракции субстрата, находившейся в пробе, показал крайне низкую степень корреляции (коэффициент линейной корреляции Спирмена не превышал сотых долей и не показал выраженной зависимости ни от одного из факторов) (рис. 5).

В целом, число видов макробентоса, обнаруженных нами в пробах, много ниже, чем описано для прол. Невельского в работе Лабая [2004]. Полигон исследований СахНИРО охватывает большую акваторию и литоральную зону, что и объясняет высокое разнообразие видов (97). В обширной по фактическому материалу и пространственному охвату работе по фауне двустворчатых моллюсков Амурского лимана и северной части Татарского пролива, выполненной экспедициями ИБМ ДВО РАН [Kamenev, Nekrasov, 2012] приводятся сведения о 41 виде двустворчатых моллюсков. Однако, данные о видовом богатстве фауны
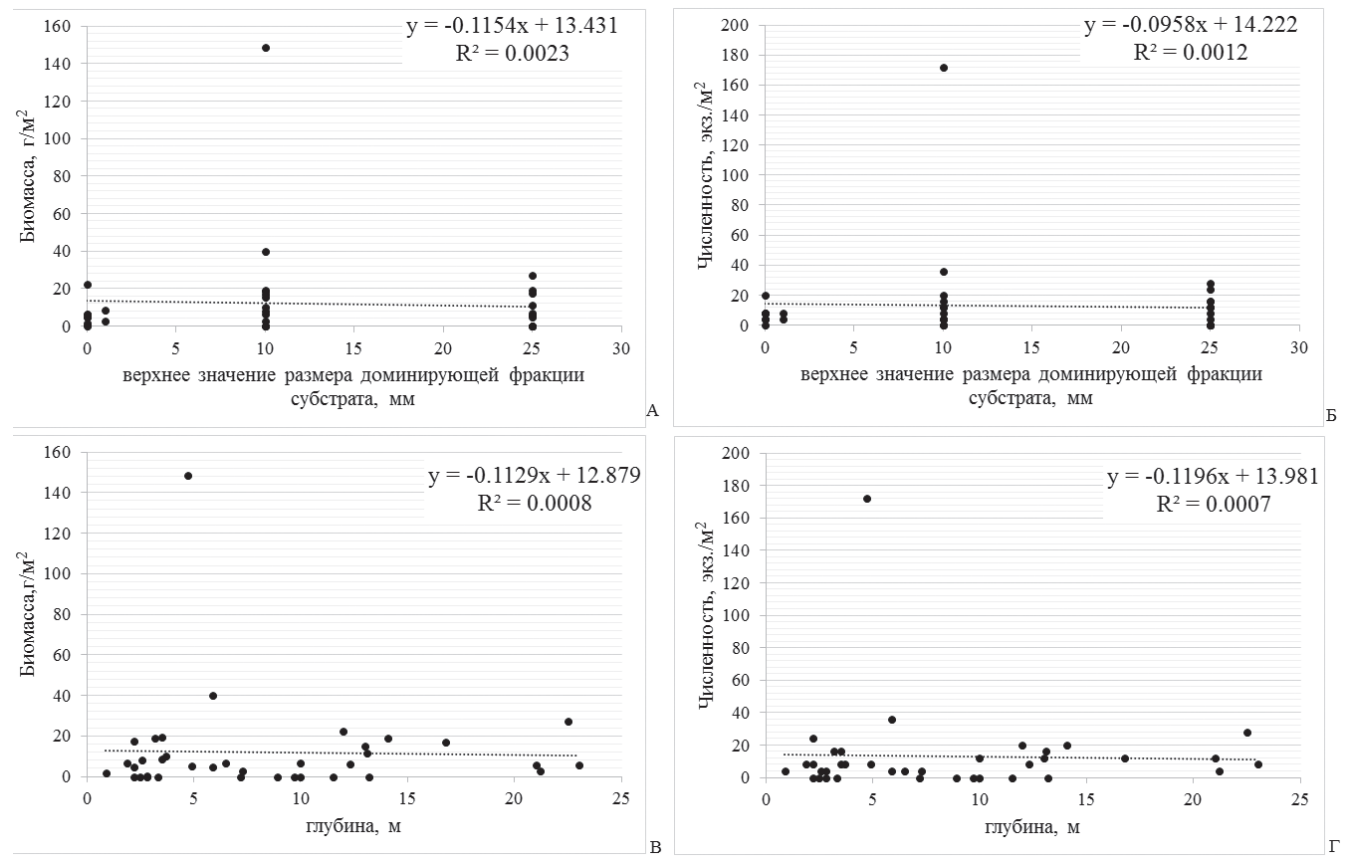

Рис. 5. Анализ линейной корреляции параметров макробентоса от доминирующей фракции в пробе грунта $(\mathbf{A}, \mathbf{~ Б )}$ и глубины $(\mathbf{B}, \mathbf{\Gamma})$.

Fig. 5. Analysis of the linear correlation of macrobenthos parameters with the dominant fraction in the bottom sample $(\mathbf{A}, \mathbf{B})$ and depth $(\mathbf{B}, \boldsymbol{\Gamma})$. 
двустворчатых моллюсков для локального района прол. Невельского не выделяются и сравнение этого показателя с полученным нами не представляется возможным.

Заслуживающим отдельного внимания фактом является не только бедный видовой состав, но практически моновидовой состав макробентоса в пробах с тотальным преобладанием эвригалинного вида M. balthica, который и ранее был отмечен как самый массовый и распространенный. Сопутствующих массовых видов двустворчатых моллюсков, широко описанных в работах по Амурскому лиману ( $C$. japonica и др.) нами не обнаружено. Отсутствие макробентоса характерно для станций, вероятно, с максимальными условиями гидродинамики, что подтверждает наличие в составе субстратов пробы грубообломочного материала, характерного именно для таких районов. Бедность состава и обилия макробентоса подтверждает статус прол. Невельского, как района с жесткими, изменчивыми экологическими условиями, препятствующими формированию устойчивых и богатых по составу и массе сообществ.

\section{Благодарности}

Авторы выражают искреннюю признательность за помощь в идентификации личинок Gastropoda, Decapoda, Cirripedia и Polychaeta сотрудникам ННЦМБ ДВО РАН В.А. Куликовой, О.М. Корн и В.А. Омельяненко.

\section{Литература}

Волков А.Ф. 2008. Методика сбора и обработки планктона и проб по питанию нектона (пошаговые инструкции) // Известия Тихоокеанского научно-исследовательского рыбохозяйственного центра (Известия ТИНРО). Т. 154. С. 405-416.

Долганова H.T., Степаненко И.Г. 2000. Сезонная и межгодовая изменчивость планктона Японского моря // Известия Тихоокеанского научно-исследовательского рыбохозяйственного центра (Известия ТИНРО). Т. 127. С. 242-265.

Дуленина П.А. 2013. Видовой состав двустворчатых моллюсков западной части Татарского пролива Японского моря // Бюллетень Дальневосточного малакологического общества. Вып. 17. C. $27-78$.

Дуленина П.А. 2018. Фауна и распределение двустворчатых моллюсков северо-западной части Татарского пролива и Амурского лимана: Автореф. дисс. ... канд. биол. наук. Хабаровск: СоветскоГаванская городская типография. $25 \mathrm{c}$.

Евсеев Г.А., Колотухина Н.К. 2008. Сравнительная морфология и проблемы таксономии пелагических личинок семейства Mytilidae (Mollusca: Bivalvia) залива Петра Великого Японского моря // Бюллетень Дальневосточного малакологического общества. Вып. 12. С. 5-41.

Инструкиия по количественной обработке морского сетного планктона. 1982. Владивосток: ТИНРО. 29 с.

Касьянов В.Л., Крючкова Г.А., Куликова В.А., Медведева Л.А. 1983. Личинки морских двустворчатых моллюсков и иглокожих. М.: Наука. 215 с.

Кобякова 3.И. 1959. Бентос северной части Татарского пролива и его значение для питания рыб // Известия Тихоокеанского научно-исследовательского рыбохозяйственного центра (Известия ТИНРО). 1959. Т. 47. С. 50-61.

Колбин К.Г. 2010. Размножение и развитие некоторых массовых видов переднежаберных брюхоногих моллюсков залива Петра Великого Японского моря: Автореф. дисс. ... канд. биол. наук. Владивосток: ДВГТУ. 23 с. 
Корн О.М., Куликова В.А. 1997. Исследования личиночного планктона в российских водах Японского моря // Биология моря. Т. 23, № 1. С. 3-14.

Корниенко Е.С., Корн О.М. 2010. Определитель личинок крабов инфраотряда Brachyura северозападной части Японского моря. Владивосток: Дальнаука. 120 с.

Куликова В.А., Колотухина Н.К. 1989. Пелагические личинки двустворчатых моллюсков Японского моря. Методы, морфология, идентификация. Препринт № 21. Владивосток: ДВО АН СССР. 60 с.

Куликова В.А., Колотухина Н.К., Омельяненко В.В. 2013. Пелагические личинки двустворчатых моллюсков Уссурийского залива Японского моря // Биология моря. Т. 39, № 6. С. 452-458.

Куликова В.А., Колотухина Н.К., Омельяненко В.В. 2014. Пелагические личинки двустворчатых моллюсков Амурского залива Японского моря // Биология моря. Т. 40, № 5. С. 342-352.

Куликова В.А., Колотухина Н.К., Омельяненко В.А. 2017. Личинки двустворчатых моллюсков в меропланктоне прибрежной части залива Анива (южный Сахалин, Охотское море) // Бюллетень Дальневосточного малакологического общества. Вып. 21, № 1/2. С. 143-154.

Куликова В.А., Корн О.М. 1999. Исследования меропланктона прибрежных вод Сахалина и Камчатки // Известия Тихоокеанского научно-исследовательного рыбохозяйственного центра (Известия ТИНРО). Т. 126. С. 564-571.

Лабай В.С. 2004. Макробентос пролива Невельского // Труды Сахалинского научно-исследовательского института рыбного хозяйства и океанографии СахНИРО (Труды СахНИРО). Т. 6. C. $305-330$.

Лоция Татарского пролива, Амурского лимана и пролива Лаперуза. 2003. С.-Пб.: МО РФ. 436 с.

Микулич Л.В., Родионов Н.А. 1975. Весовая характеристика некоторых зоопланктеров Японского моря // Гидробиологические исследования в Японском море и Тихом океане. Владивосток: ДВНЦ АН СССР. С. 75-87.

Мурина В.B. 2005. Определитель пелагических личинок многощетинковых червей (Polychaeta) Черного моря. Севастополь: ЭКОСИ-Гидрофизика. $67 \mathrm{c.}$

Надточий В.А., Гальшева Ю.А. 2012. Ретроспективный анализ количественного распределения макробентоса в северной части Японского моря // Известия Тихоокеанского научно-исследовательского рыбохозяйственного центра (Известия ТИНРО). Т. 168. С. 184-202.

Полтаруха О.П., Корн О.М. 2008. Атлас-определитель личинок усоногих раков (Cirripedia: Thoracica) прибрежных вод России. Москва: КМК. 152 с.

Рекомендации по экспресс-обработке сетного планктона в море. 1984. Владивосток: ТИНРО. 31 с.

Семенихина О.Я., Колотухина Н.К., Евсеев Г.А. 2006. Морфология личинок двустворчатых моллюсков семейства Veneridae (Bivalvia) Японского моря // Зоологический журнал. Т. 85, № 9. C. $1067-1075$.

Скарлато О.А. 1981. Двустворчатые моллюски умеренных широт западной части Тихого океана. Л.: Наука. 480 с.

Ушаков П.В. 1953. Фауна Охотского моря и условия ее существования. Л.: Изд-во АН СССР. 460 с.

Шиилько Т.С., Шевченко Г.В. 2018. Влияние приливно-отливной динамики на обмен меропланктона (Bivalvia, Gastropoda) между лагуной Буссе и прилегающей морской акваторией залива Анива // Известия Тихоокеанского научно-исследовательского рыбохозяйственного центра (Известия ТИНРО). Т. 195. С. 92-110.

Kamenev G.M., Nekrasov D.A. 2012. Bivalve fauna and distribution in the Amur River estuary - a warmwater ecosystem in the cold-water Pacific region// Marine Ecology Progress Series. V. 455. P. 195-210.

Miyazaki I. 1962. On the identification of lamellibranch larvae // Bulletin of the Japanese Society of Scientific Fisheries. V. 28. P. 955-966.

Rees C.B. 1950. The identification and classification of lamellibranch larvae // Hull Bulletins of Marine Ecology. V. 3. P. 73-104.

Sirenko B.I. (Ed.). 2013. Check-list of species of free-living invertebrates of the Russian Far Eastern seas // Explorations of the Fauna of the Seas. V. 75(83). P. 1-256.

Published online December 25, 2020 